\section{Struktura fronésis}

\section{v Aristotelově}

\section{Etice Níkomachově}

THE STRUCTURE OF PHRONESIS

IN ARISTOTLE'S NICOMACHEAN ETHICS

\title{
ROMAN HLOCH
}

Fakulta filozofická

Ostravská univerzita v Ostravě

Reální 5

70103 Ostrava

ABSTRAKT

hloch.roman@email.cz

Practical wisdom (phronesis) is a key term in Aristotle's ethics, especially when it comes to explain and to understand the right way to act. In this article, I aim at the character of practical wisdom (phronesis) in Aristotle's Nicomachean Ethics. I try to point out that practical wisdom consists of few subordinate abilities. In my interpretation, I try to explain the relation between these abilities and their specific role inside the practical wisdom (phronesis). In this article, I present plausible interpretation of character of practical wisdom and subordinate abilities.* 


\section{ÚVOD}

V Aristotelově etice představuje rozumný člověk (fronimos) vrcholný stupeň morálního vývoje. V oblasti lidského jednání (praxis) je tedy tím nejlepším typem člověka, protože jedná vždy správně. Tím se stává nejen určitým morálním vzorem pro ostatní, ale zároveň samotným ztělesněním správného jednání jako takového. Je to určitý morální typ člověka, který je sám etickou normou. ${ }^{1}$ A to dokáže proto, že oplývá rozumností (fronésis), kterou Aristotelés - spolu s uměním (techné), věděním (epistémé), moudrostí (sofia) a zřením (nús) - řadí mezi tzv. rozumové

1 Srv. Aubenque 2003, s. 45-46, 50-51; Celano 2016, s. 36-37; Konrádová 2017, s. 708; Maclntyre 1988, s. 99. zdatnosti (dianoétikai aretai). ${ }^{2}$ Co ovšem přesně ona rozumnost (fronésis) obnáší? To je otázka, na kterou není jednoduchá odpověd'. Většinou se zkoumá bud' vztah fronésis k etické zdatnosti (ethiké areté), její místo mezi ostatními rozumovými zdatnostmi (dianoétikai aretai), její vztah k jiným úkonům, např. ke zvažování (búleusis) či správnému úsudku (orthos logos), případně je také zkoumán její nárok na správné uchopení lidského jednání. Přesto však - především kvůli povaze samotných Aristotelových textů, a také složitosti a obsáhlosti daného pro-

Termín areté v tomto článku překládám jako zdatnost oproti druhému běžnému překladu jako ctnost, a to především z toho důvodu, že pojem zdatnost je méně zavádějící a více vystihuje široký záběr termínu areté jako takového. Podobný názor viz: Urmson 1995, s. 79; srv. LSJ. 
blému - je zde určitá absence koherentního a plausibilního uchopení samotné fronésis $\mathrm{z}$ hlediska její struktury a výkonu. ${ }^{3}$ Proto se $\mathrm{v}$ tomto článku zaměřím právě na strukturální prozkoumání povahy fronésis u Aristotela, přičemž svou pozornost zaměřím převážně na VI. knihu Etiky Níkomachovy. Pokusím se podat koherentní a plausibilní výklad toho, co je přesně předmětem i výměrem fronésis, zda je to jednolitá schopnost, nebo zda vyžaduje vícero prvků, které se při její činnosti zapojí, popř. v jakém vztahu tyto prvky vzájemně kooperují. Výsledkem tak bude rozbor povahy a výkonu fronésis, čímž se ukáže její struktura a to, jakým způsobem ve skutečnosti pracuje.

\section{ZÁKLADNÍ VÝMĚR FRONÉSIS}

Když Aristotelés ve VI. knize Etiky Níkomachovy pojednává o povaze fronésis, zakončuje svá stanoviska následovně:

„Zbývá tedy, že rozumnost jest s pomocí úsudku pravdivým prakticky činným stavem ve věcech, které jsou pro člověka dobré a zlé." ${ }^{4}$

Zde se zdá být klíčových hned několik věcí. Předně Aristotelés označuje fronésis jako stav (hexis), což je podle něj jakási ustálená dispozice, přičemž je to stav zároveň pravdivý, což znamená,

Někteři interpreti sice poukazují na podřazenost určitých složek či výkonů pod fronésis, tyto výklady však nejsou príliš uceleně a strukturálně uchopeny. Napr. Pakaluk 2005, s. 209, 225; Russell 2014, s. 206-208; Urmson 1995, s. 81-83.

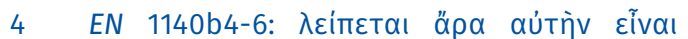

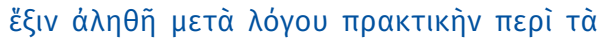

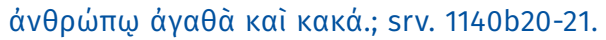
Zde, stejně jako v celém textu, se přidržuji překladu Antonína Křǐže. že s pomocí tohoto stavu bude člověk nalézat pravdu přesně v té oblasti, která fronésis přináleží. ${ }^{5}$ Tou je konkrétně oblast lidského jednání (praxis), ${ }^{6}$ což je dobře zřetelné $\mathrm{z}$ dalšího poznatku, že tento pravdivý stav je zároveň prakticky činný (praktikén). S pomocí tohoto stavu člověk prakticky koná, tzn. vykonává neboli uskutečňuje (energeia) určité jednání. Takové jednání bude správné, protože se jedná o stav, který je pravdivý s ohledem na lidská dobra a zla. Této pravdy v konkrétním případě jednání a v určité situaci je fronésis schopna dosáhnout s pomocí úsudku (meta logú).

Zde se jeví vhodné v krátkosti nastínit, co je to podle Aristotela správné jednání nebo lidská dobra v této oblasti. Aristotelovi jde o zodpovězení otázky po úkolu (ergon) lidského života, který je zároveň jeho dobrem. Tak jako je úkolem umělce umělecké dílo a úkolem sportovce sportovní výkon, tak i člověk jako specifický druh má svůj specifický úkol. Tím je život ve shodě s rozumem, protože ten odlišuje člověka od ostatních živočichů. Primárním úkolem člověka, který je jeho dobrem, je tak kontemplativní život (theória) jako takové užívání rozumu, které jej nejvíce přibližuje k božskému. Ovšem člověk je také bytostí tělesnou, živočišnou, tudíž kontemplativní život

5 Aristotelés zároveň říká, že fronésis patří té části duše, která formuje mínění (doxa) obojí se týká věcí, které mohou být jinak (allós echein). EN 1140b25-28.

6 Tato oblast je typická svou nahodilostí, nestálostí, proměnlivostí a jedinečností. Podrobný výklad nahodilosti v Aristotelově oblasti praxis podává Pierre Aubenque. Aubenque 2003, s. 78-113; srv. též zdařilý výklad Marthy Nussbaumové. Nussbaumová 2003, s. 571-584. 
pro něj nebude nikdy plně dosažitelný. Jako druhý v pořadí, ovšem vzhledem k lidské přirozenosti neméně důležitý, je život v obci a společenská interakce s příslušníky stejného druhu, tedy jednání (praxis). Tyto dva typy - kontemplativní a praktický život - tvoří směřování lidského života, jeho životní úkol (ergon), což je zdařilý lidský život neboli eudaimonia. ${ }^{7}$ Kontemplativní život je v kompetenci moudrosti (sofia), která se týká věcí neměnných, stálých a nutných, zatímco praktický život, jak už bylo ukázáno, se pojí s rozumností (fronésis), která se týká nestálých jsoucen, podléhajících změně.

Pro tuto studii je důležitá praktická stránka eudaimonie, tudíž otázku kontemplativního života ponechám stranou. V praktické oblasti člověk podle Aristotela dosahuje eudaimonie kombinací potřebných vnějších statků, dobrého životního údělu a uskutečňováním etických zdatností (ethikai aretai), které se týkají jednotlivých typů činů a jejich příslušných emocí (pathé), přičemž se nacházejí ve středu (meson) mezi extrémy přemíry a nedostatku. První dva konstituenty nemá člověk zcela ve své moci, avšak třetí již ano. ${ }^{8}$ Etické zdatnosti (ethikai aretai) jsou tedy tím, co má člověk v sobě pěstovat ${ }^{9}$ - zakládají totiž

7 Eudaimonia se často překládá jako blaženost nebo štěstí. Vzhledem k širokému významovému záběru a komplikovanosti překladu tohoto termínu budu v této studii používat původní řecký termín eudaimonia. SrV. LSJ.

8 Široce uchopené a užitečné pojetí eudaimonie u Aristotela podává Štěpán Špinka ve svém článku. Špinka 2014, s. 11-45.

9 Etická zdatnost (ethiké areté) není člověku dána přirozeně, ale člověk má prirozenou typy zdatných činů, které jsou cílem lidského jednání. Aristotelés ale zároveň upozorňuje na to, že dílčí izolovaný cíl, např. statečnost nebo pravdomluvnost, ještě nedostačuje $\mathrm{k}$ eudaimonii. Celá škála etických zdatností (ethikai aretai) je ve vztahu vzájemné provázanosti, tudíž se musí vzhledem k dosahování eudaimonie jako určitého zastřešujícího kritéria zohledňovat navzájem. ${ }^{10}$ Toto je klíčový prvek aristotelské etiky, tedy nutnost zohlednění lidského žití z celkové perspektivy. Dosáhnout dílčí zdatnosti bez zohlednění celku tedy může být chybou. Pravdomluvnost tak musí jít ruku v ruce s klidností a laskavostí, to vše podle potřeb kontextu. Zároveň je třeba neizolovat jednu konkrétní situaci a nalézt $\mathrm{v}$ ní to nejlepší jednání, ale jednající musí tuto situaci uvést do kontextu svého života jako celku, a teprve $v$ rámci tohoto celku rozhodnout, co má být v dané situaci vykonáno. Může se totiž stát, že v rámci jedné konkrétní situace je určitý čin správný a dobrý, ale s přihlédnutím $\mathrm{k}$ celkovým životním okolnostem či ve výhledu do budoucna je takový čin naopak škodlivý a špatný. Eudaimonia v praktické oblasti tak tvoří jakýsi zastřešující požadavek celkovosti žití, který je třeba mít vždy na zřeteli. ${ }^{11}$ Dílčí cíle (zdatné činy podle etické

vlohu jí nabývat, což se uskutečňuje skrze habituaci, tedy opakováním určitého typu činnosti, čimž se vypěstuje určitý zvyk. Rozumová zdatnost (dianoétiké areté) se naproti tomu ustavuje postupným učením. EN 1103a14-26.

10 EN 1097a34-1197b6, 1176b2-6, 1176b30n.; srv. Kontos 2006, s. 55-57; Synek 2011, s. 23.

11 Aristotelés mluví o jakémsi dobrém celku života či žití (eu zén holós). EN 1140a28; ve zbytku práce budu toto zastřešující 
zdatnosti) a zastřešující cíl celkovosti (eudaimonia) tedy tvoří ony správné, tj. dobré cíle lidského jednání, které ve vždy specifickém kontextu konkrétní praktické situace nalézá a uskutečňuje fronésis.

Ve shrnutí je tedy fronésis jakási ustálená dispozice, která s pomocí úsudku dokáže rozpoznat, co je v dané konkrétní praktické situaci, s přihlédnutím k požadavku celkovosti, správné, tj. dobré, a toto konkrétní správné jednání dokáže následně hned vykonat. To se jeví být jako dobrá definice pro fronésis, avšak vzhledem k široké škále probírané problematiky v Etice Níkomachově se zdá být poměrně zjednodušující, možná snad i mírně vágní. Nezbývá tedy než tuto zjednodušující definici rozšířit o další poznatky. Sám Aristotelés k tomu dokonce svým čtenářům dává jisté vodítko:

„Co jest rozumnost, pochopíme z toho, když prozkoumáme, koho nazýváme rozumným. Zdá se tedy, že znakem rozumného člověka jest schopnost správně uvažovat o tom, co jest pro něho dobré a prospěšné, ne ovšem částečně, například co jest přiměřeno zdraví nebo síle, nýbrž o tom, co slouží správně vedenému životu vůbec."12

Jak už jsem poukázal výše, u Aristotela se příklad rozumného člověka (fronimos) stává př́íkladem určitého

kritérium označovat jako „požadavek celkovosti“, prípadně "cíl celkovosti“.

12

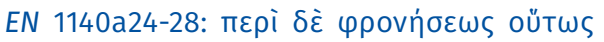

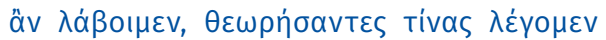

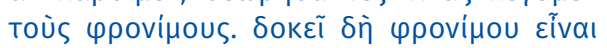

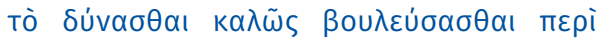

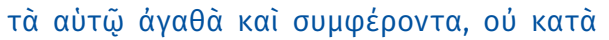

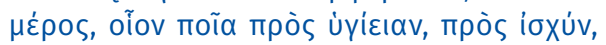

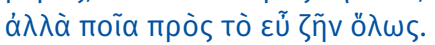

ztělesněného vzoru. Obdobná situace nastává i u samotné fronésis - pokud je třeba zkoumat její povahu, nejlépe se tak učiní s přihlédnutím k člověku, který jí oplývá. A takový člověk, tedy člověk rozumný (fronimos), oplývá schopností správně zvažovat (dynasthai kalós búleusasthai) dobré a prospěšné, což je podle výše řečeného správnost v oblasti lidského jednání (praxis). Zvažování (búleusis) jako takové, ve své základní podobě, se podle Aristotela zabývá prostředky k určitým cílům, tj. jakým způsobem dosáhnout v určité konkrétní praktické situaci v jejím specifickém kontextu nějakého cíle. Například cílem hédonika bude slast, zatímco cílem rozumného člověka (fronimos) bude uskutečňování různých etických zdatností (ethikai aretai) v dílčích situacích. Obecně jsou cíle určovány touhou (orexis), kterou Aristotelés považuje spolu s rozumem za dvě základní hybné síly jednání. ${ }^{13}$ Surovou touhu bez rozumové reflexe označuje jako žádost (epithymia), která se vztahuje k nějaké aktuální slasti (hedoné) nebo k vyhnutí se bolesti (lypé) - je tak vázána na aktuální prožitek příjemného a je dána přirozeně. Naproti tomu touha usměrněná rozumem již reflektuje možné budoucí následky i vlastní odůvodněnost - má na zř̀teli dobro, at už zdánlivé, nebo skutečné. Rozumem usměrněnou touhu Aristotelés označuje jako chtění (búlésis), což je rozumovou reflexí a zvykem vypěstovaná dispozice chtít určitý zobecněný typ cíle. ${ }^{14}$

13

14 De an. 433a9-30; 431a9-14; 414b1-13; srv. Engberg-Pedersen 1983, s. 188; Synek 2011, S. 82-83; u rozumného člověka 
Hédonik bude mít zobecněný cíl chtění (búlésis) slast, proto bude v různých situacích na tento cíl mírit. Rozumný člověk bude naopak, oproti hédonikovi, cílit na uskutečňování všech etických zdatností, se zohledněním požadavku celkovosti, protože to je jeho zobecněným cílem a předmětem jeho chtění (búlésis). Oba dva ovšem budou vzhledem $\mathrm{k}$ těmto cílům následně zvažovat (búleusis), jakým způsobem jich dosáhnout $\mathrm{v}$ dané konkrétní situaci. ${ }^{15} \mathrm{~V}$ tomto směru zvažování (búleusis) operuje v různorodém časovém rozpětí, protože jeho úkonem je zvážit prostředky vzhledem k cílům, které byly již dříve ustaveny habituací a rozumovou reflexí, tudíž se vztahuje $\mathrm{k}$ minulému, zároveň $\mathrm{s}$ tím posuzuje prostředky $\mathrm{k}$ těmto cílům vůči konkrétní probíhající situaci, což je přítomnost, a tyto prostředky - tedy konkrétní podoba daného jednání skrze způsob, jakým přesně těchto cílů dosáhnout jsou zase věcí blízké budoucnosti - výkon zvažování (búleusis) tak zahrnuje všechna tři časová rozpětí: minulost, přítomnost a budoucnost. ${ }^{16}$

(fronimos) bude veškerá touha (orexis) v souladu, nebot' habituací k uskutečňování zdatných činů zakusí slast z dobrého jednání, tudíž po takových cílech bude toužit jako po slastných i dobrých. O usměrňování touhy (orexis) a o pocitu slasti (hedoné) $z$ dobrých cílů skrze habituaci k těmto cílům viz Burnyeat 1980, s. 69-92.

15 Synek podává plausibilní schéma Aristotelova výkonu v oblasti jednání (praxis), kdy na sebe navazují jednotlivé úkony: chtění (búlésis), zvažování (búleusis), záměrná volba (proairesis) a jednání (praxis). Synek 2011, s. 80; srv. Lear 2016, s. 200; Hughes, 2013, s. 134.

16 Srv. Verbeke 1994, s. 462; taktéž Aubenque 2003, s. 132.
Rozumný člověk (fronimos) bude mít jako předměty svého chtění (búlésis) správné, tj. dobré a prospěšné zobecněné cíle, tedy cíle konstituující eudaimonii. A fronésis by tedy podle všeho měla být schopnost správně zvažovat (dynasthai kalós búleusasthai), jak přesně těchto cílů dosáhnout v konkrétní specifické situaci. Tuto tezi se zdá podporovat následující pasáž:

„Důkazem toho jest to, že rozumnými v něčem nazýváme také lidi, kteří vzhledem k dobrému účelu o něčem správně usuzují, o čem není žádného umění. Podle toho bude asi také rozumným vůbec ten, kdo správně zvažuje."17

Rozumný člověk (fronimos) tak správně usuzuje o věcech, které nejsou předmětem umění (techné), přičemž na zřeteli má dobrý cíl. Pokud se podle Aristotela fronésis týká věcí proměnlivých a nestálých - oproti moudrosti (sofia), která se týká věcí stálých, neměnných a nutných -, pak je třeba ještě určit její konkrétní pole působnosti v této oblasti. Proměnlivá a nestálá jsoucna totiž spadají bud' do oblasti vytváření (poiésis), nebo jednání (praxis). Kritériem pro rozlišení těchto dvou oblastí je perspektiva počátku a cíle. V oblasti vytváření (poiésis) je počátek určen vytvářejícím subjektem, ale samotný cíl se uskutečňuje mimo subjekt a jeho činnost, tedy ve vnějším objektu. Samotný hotový výtvor (poietón) je tak ontologicky nezávislý na subjektu i na výkonu

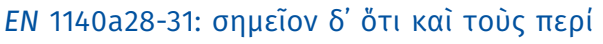

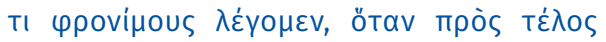

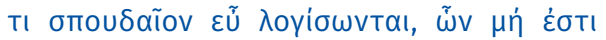

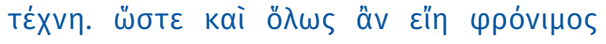
ò ßoùzutikós.
} 
vytváření. Jednání (praxis) má rovněž počátek v jednajícím subjektu, avšak oproti vytváření (poiésis) se cíl uskutečňuje skrze subjekt a jeho činnost. Vykonané jednání (prakton) je tudíž ontologicky provázané se subjektem. ${ }^{18}$ Zatímco sochař tesá sochu jako vnější výtvor, který je po jeho zhotovení nezávislý na něm samém, tak statečný člověk jedná statečně kvůli statečnému jednání a proto, aby byl sám statečný.

Schopnost nahlížení pravdy a zdárného uskutečnění v oblasti vytváření (poiésis) spadá do kompetence umění (techné). Tak sochař oplývá uměním (techné), pokud dokáže zdárně vytesat sochu s pomocí pravdivého úsudku. ${ }^{19} \mathrm{O}$ daném procesu dokáže předem správně usuzovat, pokud je to skutečný umělec - musí vybrat materiál, nářadí, představit si podobu svého výtvoru apod. To, zda má umělec ještě další cíl v podobě jiného díla, nehraje pro jeho momentální tvořivou činnost a aktuální vytvářené dílo žádnou roli - jednotlivá jeho díla jsou na sobě nezávislá, stejně jako jsou již ve svém uskutečněném, tj. hotovém stavu ontologicky nezávislá na něm samém a na jeho činnosti. O takovéto oblasti ale rozumný člověk (fronimos) neusuzuje. Aristotelés se tak zde opět snaží zdůraznit, že fronimos je ten, který správně usuzuje s ohledem na dobré cíle nestálé a proměnlivé oblasti lidských činností, ale tyto cíle nejsou předmětem umění (techné), tudíž se nevztahují na oblast vytváření (poiésis), ale

EN VI, 4; 1105a27-35; Kontos 2006, s. 54-55.

Tím se liší od ne-umění (atechnia), které sice také dokáže tvořit, ale s klamným úsudkem. EN 1140a20-23. na oblast lidského jednání (praxis), kde jsou důležité jednotlivé dílčí cíle i zastřešující prvek celkovosti žití. ${ }^{20}$ Vzhledem $k$ těmto praktickým cílům tedy fronimos správně usuzuje, tzn. správně zvažuje (búleusis) prostředky $\mathrm{k}$ nim vedoucí. V tomto směru Aristotelés jen potvrdil svá předchozí stanoviska. S ohledem na výše zmíněné lze o fronésis předběžně říci následující:

1/ orientuje se výhradně na bytostně lidskou oblast jednání (praxis);

2/ je to ustálená dispozice (hexis) nalézat a také vykonávat správné činy;

3/ má na zřeteli dobré dílčí cíle (uskutečňování ethikai aretai) i zastřešující požadavek celkovosti (eu zén holós; eudaimonia);

4/ správně zvažuje (búleusis) o tom, jak dosáhnout těchto cílů v konkrétní situaci.

\section{FRONÉSIS A PERSPEKTIVA ZVAŽOVÁNÍ}

Schopnost správně zvažovat (dynasthai kalós búleusasthai) se tak zdá být esenciální vlastností rozumného člověka (fronimos). Tudíž fronésis by se jevila jako schopnost, která je orientovaná výhradně na posuzování prostředků $\mathrm{k}$ předem stanoveným cílům, přičemž těmito cíli samotnými by se již nezabývala. ${ }^{21}$ Je ovšem fronésis skutečně takto jednotvárná? Určitá vodítka k odpovědi

20 Užitečnou komparaci fronésis a umění (techné) podává Hughes. Hughes 2013, s. 119-125; srv. Tessitore 1996, s. 43.

21 To koresponduje s Aristotelovým tvrzením, že etická zdatnost (ethiké areté) určuje cíle jednání, zatímco rozumnost (fronésis) se zaobírá prostředky k těmto cílům. EN 1144a7-9; 1145a5-6. 
na tuto otázku jsou již obsažena ve výše zmíněných citacích, ovšem zde bude vhodné podívat se také blíže k samotné správnosti ve zvažování (búleusis) a porovnat ji s danými vodítky. Aristotelés píše:

„Je-li tedy znakem lidí rozumných učinit správnou rozvahu, bude asi rozvážnost správností prospěšných prostředků k nějakému účelu, o kterém rozumnost má pravdivé mínění.“22

Rozvážnost (eubúlia) je tedy správné zvažování (búleusis) toho, jakými prostředky dosáhnout cílů, které má fronésis na zřeteli díky chtění (búlésis). Tyto cíle budou vždy dobré, protože fronésis je ustálená dispozice (hexis) nacházet a vykonávat pravdu v oblasti lidského jednání (praxis) - touto pravdou je pak správné jednání. A správnost stanovených cílů, tj. to, že jsou dobré, zajištuje habituací získaná etická zdatnost (ethiké areté) ve své komplexitě, spolu s požadavkem celkovosti. A způsob, jakým přesně a nejlépe v dané konkrétní kontextuální situaci dosáhnout těchto správných cílů, je v kompetenci rozvážnosti (eubúlia). Ta je tedy nejen správností v procesu zvažování (búleusis) prostředků $\mathrm{k}$ cíli, ale také se musí vztahovat výhradně ke správným, tj. dobrým cílům - toto jsou dvě klíčová kritéria, pokud jde o rozvážnost (eubúlia).

Podle výše zmíněného by se tak mohlo zdát, že fronésis je totožná s rozvážností (eubúlia), protože se jedná o rozumovou zdatnost (dianoétiké areté),

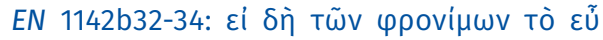

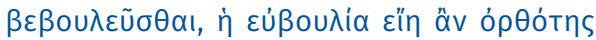

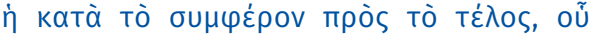

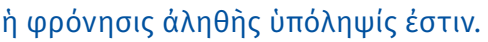

jež dokáže správně zvažovat prostředky $\mathrm{k}$ dobrým cílům, které jsou ustavené etickou zdatností (ethiké areté) a celkovostí žití. $\mathrm{Z}$ tohoto pohledu by se tedy fronésis zabývala pouze prostředky, ale nikoli cíli. ${ }^{23}$ Celá situace by v tomto případě působila plausibilně, ovšem je zde několik záležitostí, které tuto interpretaci poněkud ztěžují. ${ }^{24}$ Předně Aristotelés zdůrazňuje, že se nejedná o zvažování (búleusis) s ohledem na dílčí cíle (kata meros), ale rozumný člověk (fronimos) má schopnost správně zvážit a posoudit, co je pro něj v oblasti lidského jednání (praxis) dobré a prospěšné z celkového pohledu žití (eu zén holós). Celkovost v oblasti praxis je zastřešující prvek, a tím není nic jiného než samotná eudaimonia. Rozumný člověk (fronimos) tak sice má na zřeteli jednotlivé dobré dílčí cíle jako statečnost, uměřenost apod., ovšem tyto cíle nejsou nikdy izolovány. Jejich vzájemná souvislost a propojenost tvoří přesně to, co je požadavkem eudaimonie, tedy celkovost žití v praktické oblasti. ${ }^{25}$ V konkrétní kontextuální situaci tak rozumný člověk (fronimos) posuzuje a zvažuje nejen prostředky $\mathrm{k}$ danému cíli či cílům, ale zároveň také relevanci vztažnosti těchto jednotlivých cílů vůči sobě navzájem a především vůči celkovému zastřešujícímu požadavku eudaimonie. Být pravdomluvný totiž může

Tuto interpretaci, že proces zvažování (búleusis) se zaobírá výhradně prostředky k cílům, zastávají například: Fortenbaugh 2006, s. 189-198.; Tuozzo 1991, s. 193-212.

24 Stejně tak Urmson pokládá za chybu omezovat fronésis pouze na výkon rozvážnosti (eubúlia). Urmson 1995, s. 81.

25 Srv. Aubenque 2003, s. 117; Celano 2016, s. 34; Hardie 1968, s. 213; Wiggins 1980, s. 224-225. 
znamenat, že izolovaný cíl pravdomluvnosti povede $\mathrm{k}$ tomu, že člověk svému příteli řekne něco, co je sice pravdivé, ale co jej může hluboce ranit nebo způsobit mnohem více potíží do budoucna. Nejde tedy jen o to, říci př́íteli pravdu, ale také o správnou volbu slov a posouzení dané situace s ohledem na budoucnost. Požadavek pravdomluvnosti je třeba poměřit např. s požadavkem laskavosti, klidnosti apod. $^{26}$

Úkonem rozumného člověka (fronimos) tak nebude správné zvážení prostředků k jednomu izolovanému, byt' dobrému cíli, ale také zvážení prostředků k dosažení cíle celkovosti, tj.eudaimonie, což vyžaduje i posouzení jednotlivých těchto dílčích cílů vůči sobě navzájem v dané konkrétní situaci. ${ }^{27} \mathrm{Ne}$ lze tedy tvrdit, že se rozvážnost (eubúlia) zabývá pouze posouzením prostředků k jednomu cíli, ale zabývá se také posouzením relevance dílčích cílů vůči sobě navzájem, což je posouzení prostředků vůči celkovému a zastřešujícímu cíli eudaimonie. ${ }^{28}$ Nejedná se však o posouzení

White dokonce zdůrazňuje, že konflikt různých dober je v Aristotelově etice nevyhnutelný, čehož si byl sám Aristotelés dobře vědom. White 1995, s. 269; srv. Wiggins 1980, s. 233; Aristotelés navíc sám říká, že rozumný člověk (fronimos) nezohledñuje v jednání pouze své vlastní dobro, ale i dobro obce. EN 1179a9-17.

Srv. Celano 2016, s. 37; Hughes 2013, s. 133-135; Rorty 1988, s. 140; Sorabji 1996, s. 28-29; Schollmeier se pokusil zacílení fronésis na prostředky i cíle vyřešit tak, že jí přisoudil dvě rozdílné funkce: (i) intutivní, která se zaobírá cíli, a (ii) diskurzivní, která zvažuje prostředky k těmto cílům. Schollmeier 1989, S. 124.

Srv. Pakaluk 2005, s. 137-140; Russell 2014, s. 204-206; proto je zde rozdíl mezi zvažováním (búleusis) jako takovým, které se může adekvátnosti těchto jednotlivých cílů jako takových, protože ty jsou ze své podstaty dobré, a jsou ustaveny jako zobecněné cíle chtění (búlésis) skrze habituaci, určené etickou zdatností (ethiké areté). ${ }^{29}$ Cílem posouzení rozvážnosti (eubúlia) je jen jejich aplikace a kooperace $\mathrm{v}$ jednotlivých situacích podle zastřešujícího kritéria celkovosti dobrého žití.

Dále by se mohlo také zdát, že výkon fronésis je omezen na výkon rozvážnosti (eubúlia), což by bylo určité zpřesnění předchozí Aristotelovy zjednodušující definice fronésis (bod 4). Podle mého názoru je však rozvážnost (eubúlia) jen jednou z více částí fronésis, která je tak komplexnější a sofistikovanější schopností. Předně je třeba pohlédnout několik kroků zpátky do II. knihy Etiky Níkomachovy, kde Aristotelés pojednává o své nauce o středu (meson). Střed jakožto zdatnost (areté) se nachází mezi extrémy přemíry a nedostatku, ale nikoli jako rigidní střed $\mathrm{v}$ matematice. Etický střed je pohyblivý a pružný podle kontextu dané situace, protože se týká proměnlivých a nestálých jsoucen, takže

zabývat pouze prostředky k jednomu izolovanému cíli, oproti rozvážnosti (eubúlia), která disponuje reflexí jednotlivých dobrých cílů vưči sobě navzájem a vưči zastřešujícímu principu eudaimonie, díky čemuž jí může oplývat pouze člověk rozumný (fronimos); srv. Celano 2016, s. 41-42.

29

Ani fronimos, ani třeba takový hédonik již neuvažuji o tom, jakých cílů chtějí dosáhnout. Jejich touha (orexis) po těchto cílech je již natolik ustálená, že jsou ty to cíle dlouhodobě předmětem jejich žádosti (epithymia) a chtění (búlésis). Zvažování (búleusis) se tedy rozhodně netýká cilů v tom smyslu, že by kriticky zkoumalo, zda je daný jedinec skutečně chce. Srv. Kosman 2014, s. 292. 
není zdaleka lehké jej zasáhnout. Co však podle Aristotela určuje, kde takovýto etický střed v daném konkrétním případě leží, je správný úsudek (orthos logos). ${ }^{30} \mathrm{~K}$ jeho vysvětlení se Aristotelés slíbí vrátit později, což částečně, avšak ne zcela uspokojivě činí na začátku VI. knihy. ${ }^{31}$ Aristotelés nejprve rekapituluje své závěry ze II. knihy, a to následovně:

„Ježto jsme však dříve řekli, že jest tř̀eba dávat přednost středu, a nikoli nadbytku ani nedostatku, a středem jest to, co určuje správný úsudek, objasněme to blíže. Ve všech uvedených stavech totiž, jakož i v ostatních, jest jakýsi cíl, k němuž hledí, směřuje a tíhne ten, kdo má rozum, a jest jakýsi výměr středností, o kterých pravíme, že jsou uprostřed mezi nadbytkem a nedostatkem, ježto odpovídají správnému úsudku.“32

Střednost (mesotés) je stav mezi nadbytkem a nedostatkem, který je pružný

30 Rozhodně se přikláním k překladu orthos logos jako správný úsudek, oproti překladu jako správné pravidlo. Předně je Aristotelova etika vůči pravidlům spíše kritická, dále pak orthos logos nepředstavuje jakýsi přehled či šablonu aplikace pravidel pro správné jednání, ale jedná se o usuzování v praktických záležitostech, které je dle svého výkonu správné, tj. míři ke správnému jednání. Srv. Pakaluk 2005, s. 214; Synek 2011, s. 134.

31 Srv. Tessitore 1996, s. 42-43.

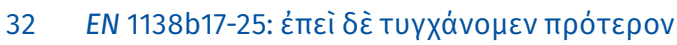

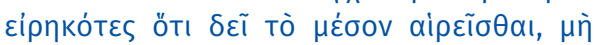

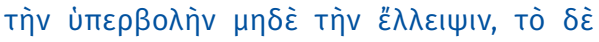

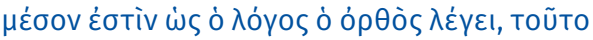

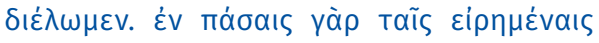

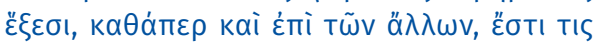

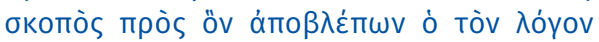

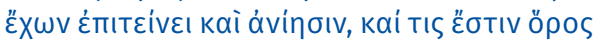

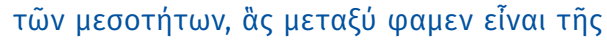

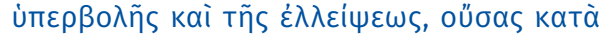
Tòv ó $\rho \theta$ òv $\lambda$ óyov. v závislosti na specifikacích dané situace. Takovýto stav střednosti je pak správné jednání, je to zdatnost (areté), a s ohledem na specifický kontext dané situace jej určuje právě správný úsudek (orthos logos). Jak jsem už vyložil výše, správné jednání v dané situaci zajištuje fronésis tak, že vzhledem $\mathrm{k}$ danému kontextu posoudí jednotlivé dílčí cíle s ohledem na celkovost žití, což představuje zastřešující princip eudaimonie, a zároveň posoudí prostředky $\mathrm{k}$ tomuto vyhodnocenému cíli či cílům. Tím dokáže fronésis $\mathrm{v}$ dané situaci dosáhnout správného jednání, což je de facto střed (meson). V tomto směru je výkon fronésis totožný s výkonem rozvážnosti (eubúlia). A jelikož to, co podle Aristotela určuje střed (meson), je správný úsudek (orthos logos), pak ten je v tomto směru dle výkonu totožný s rozvážností (eubúlia) a fronésis.

\section{USUZOVACI VÝKON FRONÉSIS}

Proč by ovšem Aristotelés používal na jeden jediný výkon tři různé termíny? Dle mého názoru je tato teze o totožnosti výkonů fronésis, rozvážnosti (eubúlia) a správného úsudku (orthos logos) do určité míry správná, ale nekompletní a nevyčerpává všechny úkony, které správný úsudek (orthos logos) a především fronésis vykonávají. Předně je třeba konstatovat, že výkon rozvážnosti (eubúlia) byl již prozkoumán výše - dle mého názoru je jednou z nezbytných prvků fronésis, stejně jako je i jedním z nezbytných prvků správného úsudku (orthos logos), což se pokusím vyjasnit níže.

Podle první zmíněné definice v tomto článku je fronésis stavem (hexis), 
tj. ustálenou dispozicí nacházet a vykonávat pravdu v oblasti lidského jednání (praxis), a touto pravdou jsou správné dílčí činy vzhledem ke kontextu určité situace, spolu se zastřešujícím požadavkem celkovosti žití. Podle této definice toho všeho fronésis dosahuje s pomocí úsudku (meta logú), tedy s pomocí nepř́liš specifikovaných rozumových schopností. A jelikož se fronésis týká správného jednání, tj. správně stanovených cílů, správně vyhodnoceného kontextu a správně posouzených prostředků, pak i výkon rozumu musí být správný. To znamená, že i onen úsudek (logos), s jehož pomocífronésis dosahuje pravdy v oblasti lidského jednání, musí být správný. ${ }^{33} \mathrm{~A}$ přesně na tento prvek výkonu fronésis podle mého názoru odkazuje správný úsudek (orthos logos) ${ }^{34}$ je to přesně ta část fronésis, která odkazuje na veškerou usuzovací kognitivní aktivitu v rámci fronésis. Proto Aristotelés neváhá použít následujícího silného srovnání:

„... zdatností (areté) jest totiž nikoli stav, který jest pouze ve shodě se správným úsudkem, nýbrž stav s pomocí

Srv. s komentářem Joachima k výše citované pasáži. Joachim 1955, s. 164. V tomto směru se také fronésis liši od moudrosti (sofia). Moudrost se jako rozumová zdatnost (dianoétiké areté) zabývá stálými, neměnnými a nutnými počátky a tím, co z nich vyplývá, čímž v sobě kombinuje prvky zření (nús) a vědění (epistémé). Přináleži tak jiné části duše, než k jaké se pojí usuzování (logos), které je doménou fronésis. EN 1143b15-18; srv. poznámku Antonína Křiže k této pasáži; srv. také: Špinka 2014, s. 31.

Aristotelés sám dokonce občas hovoři o správném úsudku (orthos logos) jednoduše jen jako o úsudku (logos). EN 1114b29, 1115b12; srv. Pakaluk 2005, s. 214. správného úsudku. Správný úsudek však v těch věcech jest rozumnost." ${ }^{\text {"35 }}$

Zdatnost (areté) je podle Aristotela stav (hexis), který je dosahován s pomocí správného úsudku (meta tú orthú logú), a ten je zde výslovně ztotožněn s fronésis. Je ale třeba poznamenat, že samotný správný úsudek (orthos logos) není vykonavatelem správného jednání, ale správné jednání se vykonává s jeho pomocí. ${ }^{36} \mathrm{~V}$ tomto ohledu se tedy jedná o usuzovací aktivitu, ale rozhodně se nejedná o uskutečněné vykonání daného činu. Na základní rovině lze tedy výkon fronésis rozdělit na část usuzovací a rozkazovací, nebo jinak řečeno na část rozumovou a vykonávací. Ona usuzovací neboli rozumová část je právě správný úsudek (orthos logos) - a v tomto ohledu je totožný s fronésis. ${ }^{37}$

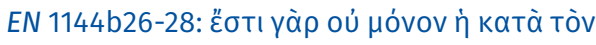

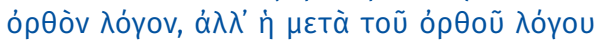

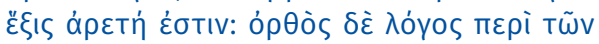

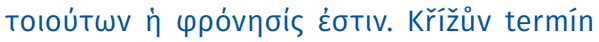
ctnost zde pro potřeby práce nahrazuji terminem zdatnost.

36 Tessitore hovoří o správném úsudku (orthos logos) jako o zdroji morální vize, která vychází zevnitř jedince. Tessitore 1996, s. 46.

37 Urmson rozlišuje zvažovací (búleusis) a vykonávací (jednajíci) schopnosti s ohledem na etickou zdatnost (ethiké areté), která by měla být vedena pomocí souzení ohledně správného jednání ve variaci proměnlivých praktických situací - toto je dle něj správný úsudek (orthos logos). Dále ale nespecifikuje to, jak se správný úsudek (orthos logos) konkrétně vztahuje ke zvažování (búleusis) a vykonávací schopnosti. Urmson 1995, s. 86; vztah těchto tři prvků predstavuji v tomto článku, přičemž všechny tyto tři prvky spojuji s fronésis. 


\section{ROZKAZOVACI vÝKON FRONÉSIS}

Zkoumání usuzovací části ponechám na chvíli stranou, ale později se $\mathrm{k}$ ní ještě vrátím. Nyní je třeba se blíže zaměřit na druhou, tedy rozkazovací neboli vykonávací část fronésis. Co se týče jednání, tak správnost v daném kontextu konkrétní situace nestačí jen vyhodnotit a nalézt, ale je třeba takovýto správný čin i vykonat, tedy uskutečnit. Jinak by se totiž vůbec nejednalo o případ jednání, ale pouze o případ usuzování. Rozkazovací neboli vykonávací část je tak neméně důležitá než část usuzovací. ${ }^{38} \mathrm{Z}$ tohoto hlediska Aristotelés zmiňuje určitou paralelu, která zní následovně:

„Jest jakási schopnost, která bývá nazývána dovedností; ta jest taková, že dovede konat to, co směřuje $\mathrm{k}$ danému cíli, a dosíci toho. Je-li tedy cíl krásný, jest hodna chvály, je-li špatný, jest zchytralostí; proto říkáme, že rozumní lidé jsou dovední, a říkáme to také o lidech zchytralých. Rozumnost tou schopností není, ale není bez ní.“39

Dovednost (deinotés) je určitá specifická schopnost, díky níž člověk dokáže

Urmson upozorňuje, že je podstatný rozdíl mezi naplánováním určité operace a uskutečněním tohoto plánu, a tento rozdíl ve výkonu obou operací by se podle něj rozhodně neměl podceňovat. Urmson 1995, s. $82-83$; srv. Burnyeat 1980 , s. 81 ; Russell 2014, s. 207.

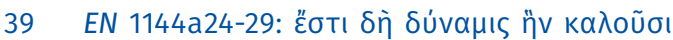

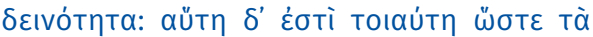

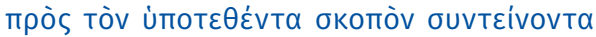

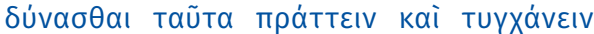

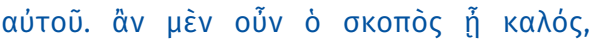

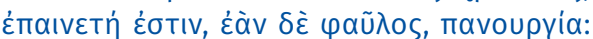

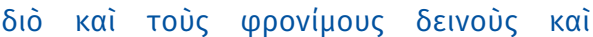

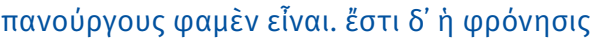

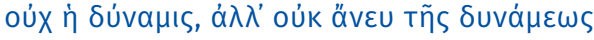
Taútทs. dosáhnout určitého cíle tím, že vykoná potřebné kroky k jeho uskutečnění. Toto je zcela jasně patrné z Aristotelova popisu, totiž schopnost uskutečnit daný cíl, dosáhnout jej pomocí určitých prostředků. Je to tedy vskutku vykonávací neboli rozkazovací schopnost. Ovšem tato dovednost (deinotés) sama o sobě, jak Aristotelés upozorňuje, není totožná s fronésis. Výraz deinotés může označovat chytrost, mazanost, ale také přísnost nebo hrozivost; zároveň je odvozen od termínu deinos, což se dá přeložit jako hrozný, strašný, ohromný, ale také chytrý nebo dovedný ( $L S J)$. Často se termíny deinos nebo deinotés užívaly v oblasti řečnictví jako jakási dovednost vyslovit určitou řeč. ${ }^{40}$ Aristotelés užívá výraz deinotés šířeji pro pokrytí různé škály uskutečnění cílů, takže se může jednat o zdárně pronesenou řeč nebo také o zdárně vykonaný čin, at už má jakýkoli morální rozměr. Oplývat touto dovedností tak může i člověk lživý apod. Díky ní totiž dokáže dosáhnout svého cíle - lži. V tomto ohledu je dovednost (deinotés) morálně indiferentní. Morální rozměr je zde určen pouze cíli, kterých se skrze ni dosahuje. ${ }^{41}$ Pokud jsou tedy cíle špatné, bude i ona špatná - bude zchytralostí (panúrgia).

40 Toto lze nalézt například u Isokrata (Isoc. 1.4; 15.16; 15.197). Občas také uživá výrazu deinos jako označení něčeho hrozného, strašného (Isoc. 2.23; 15.42). Také lze u něj nalézt výraz deinon, když mluví sám o sobě jako o chytrém či bystrém (Isoc. 15.15).

41 Tessitore správně zdůrazňuje fakt, že v rámci fronésis je kličová její propojenost s etickou zdatností (ethiké areté), která konstituuje správné cíle, bez čehož je dovednost (deinotés) sama o sobě morálně neutrální. Tessitore 1996, s. 45. 
Pokud je ovšem využita pro dosažení správného, tj. dobrého cíle, pak je sama dobrá a zasluhuje si chválu. Jak jsem řekl výše, fronésis má na zřeteli pouze správné cíle s ohledem na lidské jednání. A vzhledem ke konkrétnímu kontextu dané situace dokáže správně posoudit a vyhodnotit způsob, jakým těchto cílů $\mathrm{v}$ daném případě dosáhnout. To vše ovšem náleží do oblasti usuzování, avšak danou podobu vyhodnoceného činu je třeba ještě uskutečnit, je třeba jej vykonat. A k tomu je třeba schopnost, která to dokáže. Touto schopností je podle výše řečeného dovednost (deinotés), která se tak s ohledem na správné cíle, které má na zřeteli fronésis, sama stává správnou. ${ }^{42} \mathrm{~V}$ tomto případě se dokonce ona dovednost (deinotés) sama stává součástí procesu, který je v područí fronésis.

Takže dovednost (deinotés), jelikož je sama o sobě morálně indiferentní, nemůže být $\mathrm{v}$ žádném případě zcela totožná s fronésis, ale pokud se jedná o výkon rozumného člověka (fronimos), pak je dovednost (deinotés) rozkazovací neboli vykonávací částí fronésis. Bez ní totiž nelze uskutečnit danou podobu jednání, kterou vyhodnotila usuzovací část $\mathrm{v}$ kompetenci správného úsudku (orthos logos). Mým závěrem v této chvíli je tedy to, že fronésis se skládá ze dvou

Aristotelés uvádí rozdíl mezi zdatností přirozenou (fysikos areté) a rádnou (kyrios areté) a staví jej do kontrastu s rozdílem mezi dovedností (deinotés) a rozumnostî (fronésis). Zdá se tedy, že deinotés je schopnost, která je člověku dána přirozeně, zatímco fronésis je třeba získat. EN 1144b1-17; srv. Russell 2014, s. 209; netradiční interpretaci prirozené zdatnosti (fysikos areté) podává Curzer, který ji ztotožňuje se zdatností etickou (ethiké areté). Curzer 2012. základních částí, konkrétně z části usuzovací, která je správným úsudkem (orthos logos), a části vykonávací, která je dovedností (deinotés).

Nyní je třeba se opět vrátit k usuzovací části. Tato část fronésis je to, co Aristotelés označuje jako správný úsudek (orthos logos), a zahrnuje veškeré usuzovací kognitivní úkony. Již byla řeč o rozvážnosti (eubúlia), což je správnost ve výkonu zvažování (búleusis) nejlepších prostředků $\mathrm{k}$ dobrým cílům. Tento usuzovací úkon se zaobírá nejen prostředky k jednotlivým cílům, ale rovněž posouzením těchto cílů vưči sobě navzájem a především vůči požadavku celkovosti, což představuje zastřešující princip eudaimonie jakožto správnosti celkového žití, a to vždy vzhledem ke konkrétní kontextuální situaci. Jako taková je tak rozvážnost (eubúlia) součástí usuzovací složky fronésis, tedy je součástí správného úsudku (orthos logos). ${ }^{43} \mathrm{Z}$ toho lze vidět, že fronésis jako takovou rozhodně nelze omezit pouze na výkon zvažování prostředků k cílům - její struktura a působnost je mnohem komplexnější a sofistikovanější. ${ }^{44}$

43 Kosman označuje výkon zvažování (búleusis) jako rozumovou aktivitu, popř. určitou formu myšlení, zatímco fronésis je podle něj myšlení v jednání neboli jednající myšlení. Tento názor nejde zásadně proti mé interpretací, kdy fronésis je rozumová (usuzovací) i vykonávací (jednající), přičemž rozvážnost (eubúlia) jakožto správnost ve výkonu zvažování (búleusis) je její čistě rozumovou (usuzovací) částí. Kosman 2014, s. 295.

44 Rozumný člověk (fronimos) tak není především paradigmatem etického zvažování (búleusis), jak tvrdí Konrádová. To totiž tvoři jen jednu z jeho nezbytných složek, ale rozhodně se nedá hovořit o kardinálním úkonu. Konrádová 2017, s. 708. 


\section{STRUKTURÁLNÍ POVAHA FRONÉSIS}

Jak přesně se to ovšem má se vztahem rozvážnosti (eubúlia) a správného úsudku (orthos logos)? Podle mého názoru ani ony nemůžeme zcela ztotožnit, ale opět i zde panuje určitý vztah subsumpce - konkrétně rozvážnost (eubúlia) je jednou z podřazených součástí správného úsudku (orthos logos), a to proto, že ten zahrnuje veškeré usuzovací úkony při výkonu fronésis. A rozvážnost (eubúlia) je jen jedním z těchto usuzovacích úkonů, totiž správné zvážení prostředků $\mathrm{k}$ cíli/cílům. Jaké jsou pak ty další úkony? Odpověd' na tuto otázku lze nalézt v 11. a 12. kapitole VI. knihy Etiky Níkomachovy, kde Aristotelés mluví o chápání (synesis) a uznání (gnómé). Zde je sice vztah obou schopností k fronésis nejasný, nicméně jinde je chápání (synesis) zcela explicitně označeno jako neoddělitelná součást fronésis. ${ }^{45}$ Obojí, chápání (synesis) i uznání (gnómé), se dále týkají „toho, co má být konáno“ (ta prakta), což je v kompetenci fronésis. ${ }^{46}$ O obou schopnostech mluví Aristotelés v Etice Níkomachově současně, navíc se z textu zdá, že je staví na stejnou rovinu. Tím pádem bude nejspíš nejen chápání (synesis), ale i uznání (gnómé) součástí fronésis. Zbývá tedy otázka zařazení do její struktury.

Začnu chápáním (synesis). Aristotelés sice o chápání (synesis), a především o dobré chápavosti (eusynesia) jako správnosti v tomto úkonu, mluví

$45 \quad$ MM 1197b15-17.
$46 \quad$ EN 1143a33-36. jen velmi krátce, ${ }^{47}$ čímž je komplikován jakýkoli pokus o její výklad. Přesto se o stručný výklad v rámci své studie pokusím. Aristotelés říká:

„Nebot' rozumnost jest rozkazovací - jejím účelem totiž jest to, co konat máme, nebo nemáme -; chápání však jest pouze soudící - nebot chápání a dobrá chápavost, lidé chápaví a dobře chápaví jest totéž. “"

Chápání (synesis), jakožto schopnost soudící (kritiké), je zde postaveno do kontrastu kfronésis jako ke schopnosti, která je rozkazovací (epitaktiké). Tím Aristotelés nechce říci, že by fronésis byla čistě rozkazovací, ale pouze se snaží poukázat na jednu z částí jejího výkonu, aby ji odlišil od chápání (synesis), které je čistě soudící. ${ }^{49}$ Klíčová tak je zde role chápání jako takového, protože to ze své podstaty náleží do oblasti souzení (krisis), tedy do oblasti kognitivních aktů. ${ }^{50}$ Proto Aristotelés může říci, že oplývat správností v chápání (eusynesia) ještě neznamená oplývat fronésis. Obojí se však týká praktického jednání. Jinde je chápavý člověk označen jako ten, který je schopný zvažovat (tó dynatos búleuesthai). ${ }^{51}$ Chápání (synesis) je tedy do určité míry postaveno na rovinu zvažování (búleusis). Nicméně obojí

47 SrV. EN VI, 11.

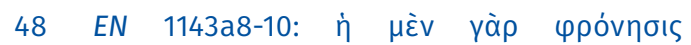

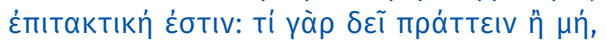

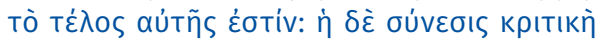

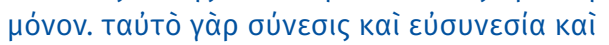

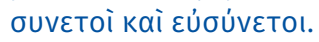

49 Srv. Reeve 2006, s. 203.

50 Krisis je u Aristotela prvek kognice, pod jejíž výkon řadí smyslové vnímání (aisthésis), obrazivost (fantasia) a myšlení (noésis). De an. 427a17-22; 432a16; De motu 700b19-21.

$51 \quad$ MM 1197b13. 
nemůže být totožné, protože Aristotelés o zvažování (búleusis) hovoří často jako o jakémsi hledání (zétésis), ${ }^{52}$ zatímco chápání je již zmíněné souzení (krisis) a také vidění (idein), ${ }^{53}$ čímž chce Aristotelés zdůraznit, že se jedná o určité pochopení, metaforicky zpozorování určité skutečnosti posuzovaných věcí. Tudíž se zdá, že zatímco zvažování (búleusis) je posuzováním prostředků k praktickým cílům spíše z hlediska hledání toho nejlepšího způsobu, tak chápání (synesis) je posuzováním prostředků k praktickým cílům $\mathrm{z}$ hlediska zpozorování, tedy pochopení toho nejlepšího způsobu. Schopnost chápat máme podle Aristotela dánu přirozeně, avšak dobrá chápavost (eusynesia) se podle něj rozvíjí až učením a zkušeností. ${ }^{54}$ Aristotelova zmínka o procesu učení navíc napovídá, že chápání (synesis) je důležitá podmínka pro konstituci samotné fronésis, protože ta se jako zástupkyně rozumových zdatností (dianoétikai aretai) získává právě učením a zkušeností. 55 Postavením na rovinu zvažování (búleusis) chtěl Aristotelés upozornit na to, že chápání (synesis) je rovněž podřazeno pod soudící část. Spolu s rozvážností

52 Např. EN 1112b20; 1142a31-32; 1142b1-3.

53 MM 1197b14.

54 EN 1143a11-15; 1143b6-14.

55 Curzer se domnívá, že fronésis zahrnuje také vysvětlení, proč (dióti) je dané jednání správné. S Curzerem v tomto směru souhlasím a sám se domnívám, že tuto znalost proč (dióti) obstarává v rámci fronésis právě chápání (synesis) či lépe řečeno správné chápání (eusynesia). Curzer 2012, s. 310; podobný názor jako Curzer zastává také Hughes, ovšem ten podle mého názoru chybně opomíjí vykonávací složku fronésis a zdůrazňuje složku usuzovací. Hughes 2001, s. 107. (eubúlia) je tak dobré chápání (eusynesia) součástí správného úsudku (orthos logos). Ale ani rozvážnost (eubúlia) spolu s dobrým chápáním (eusynesia) ještě netvoří fronésis, protože ta oplývá také vykonávací částí, kterou obstarává dovednost (deinotés). Proto onen důraz na rozkazovací charakter fronésis oproti soudícímu charakteru chápání (synesis).

Obdobná situace je také v případě uznání (gnómé), o němž však Aristotelés hovoří ještě méně než o chápání (synesis). V jednom kratičkém odstavci mluví pouze o tom, že uznání (gnómé) je jakýsi správný soud o slušnosti (tú epieikús esti krisis orthé). ${ }^{56}$ Je tedy určitým typem souzení (krisis), podobně jako chápání (synesis), proto je Aristotelés staví vedle sebe. Slušnost (epieikeia) pak podle Aristotela opravuje obecný zákon, protože ten je ustaven všeobecně, čímž nedokáže pokrýt širokou škálu proměnlivých a jedinečných situací praxe - tam, kde se na neurčitost (aoriston) praktických situací nedá aplikovat obecné pravidlo, přichází na řadu epieikeia, která toto pravidlo vhodně upraví podle dané situace. ${ }^{57}$ Uznání (gnómé) tedy bude schopnost posoudit určitou praktickou situaci $\mathrm{v}$ její specifičnosti $\mathrm{v}$ kontrastu $\mathrm{k}$ obecnému zákonu či pravidlu. ${ }^{58}$ A protože je Aristotelés staví na jednu rovinu, lze předpokládat, že uznání (gnómé), stejně jako chápání (synesis), náleží do oblasti usuzování, tudíž situace ohledně jejich

\footnotetext{
56 EN 1143a19-24.

57 EN 1137b9-19; 1137b26-32. Více k povaze obecných zákonů, pravidel a neurčitosti (aoriston) praktických záležitostí viz Nussbaumová 2003, s. 576-582.

58 Gnómé může být přeloženo i jako soudnost, rozsudek, rožrešení (LSJ).
} 
vztahu $\mathrm{k}$ fronésis bude $\mathrm{v}$ tomto případě nejspíš totožná. ${ }^{59}$

Obojí - jak dobré chápání (eusynesia), tak dobré uznání (eugnómosyné) ${ }^{60}$ se týká stejných věcí, kterými se zaobírá fronésis. Konkrétně v oblasti lidského jednání (praxis) se obojí týká nestálých a proměnlivých situací s jejich specifickými kontextuálními prvky. Obojí je zároveň kognitivním a soudícím aktem (krisis), tudíž je rázu usuzovacího. $\mathrm{Z}$ tohoto důvodu, pokud se týká samotné fronésis, tak dobré chápání (eusynesia) i dobré uznání (eugnómosyné) patří do její usuzovací části, tedy obojí je podřízeno - spolu s rozvážností (eubúlia) správnému úsudku (orthos logos).

Dosavadní interpretaci povahy a struktury fronésis podle výše uvedeného rozboru by mohlo znázorňovat následující schéma:

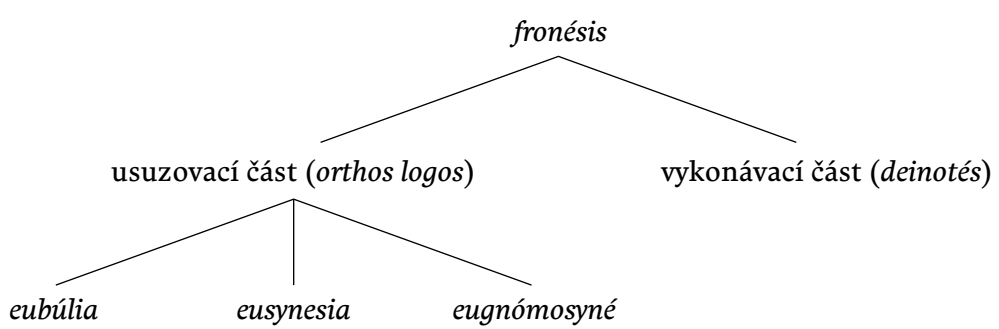

Ještě zde ovšem zbývá problematická otázka zření (nús), ${ }^{61}$ které Aristotelés

59 Srv. Engberg-Pedersen, 1983, s. 213; Pakaluk 2005, s. 225.

60 O dobrém uznání (eugnómosyné) nebo uznalosti, jak ji překládá Křižz, je explicitně zmínka až v MM 1198b34-1199a3; nicméně pokud existuje eusynesia jako správné uplatnění výkonu synesis, potom je zcela koherentní a plausibilní, pokud existuje i eugnómosyné jako správné uplatnění výkonu gnómé.

61 Přikláním se k překladu termínu nús jako žrení podle Synka, oproti původnímu Křǐžovu překladu jako rozumění. Synek 2011, 99. v EN VI, 12 staví do určité roviny s fronésis, synesis a gnómé. Zření (nús) je v oblasti teoretického rozumu jakési intuitivní nahlížení univerzálních počátků (archai) skrze důkazy (apodeixeis) z pravdivých a nutných vět, čímž uchopuje obecné a nejvyšší pojmy (horoi). V praktické oblasti pak uchopuje pojmy nejnižší a proměnlivé, které jsou vedlejší premisou praktického sylogismu. I zde se jedná o jakýsi typ rozumové intuice, díky níž se z jednotlivého získává obecné (katholú), což Aristotelés přirovnává k vnímání (aisthésis). ${ }^{62} \mathrm{Ob}$ tíže může působit jiná pasáž, která na první pohled působí jako kontradikce, když tvrdí, že fronésis je v protikladu (antikeitai) k nús, protože se zabývá nejnižšími pojmy, zatímco nús pojmy nejvyššími. ${ }^{63} \mathrm{Zde}$ je fronésis, a nikoli nús, přirovnávána k vnímání (aisthésis). Důležitý je ovšem záměr této pasáže. Hlavním tématem je totiž odlišení fronésis od vědění (epistémé), které se jako rozumová zdatnost zabývá oblastí teoretickou, nikoli praktickou. Mluví-li zde Aristotelés o nús, má zřejmě na mysli její čistě teoretický výkon, nikoli ten praktický. ${ }^{64}$ Fronésis a praktická nús jsou tedy spojeny tím, že jsou obě přirovnány $\mathrm{k}$ aisthésis. Nejedná se ovšem o smyslové vnímání vlastního předmětu smyslu (idion aisthéton) jako barvy, zvuku apod. ${ }^{65}$ Aristotelés má na mysli zvláštní

\footnotetext{
62 EN 1143a35-b5.

63 EN 1142a23-30

64 Srv. Shiner 1979, s. 380-381; EN VI, 6.

65 Srv. De an. II, 6.
} 
typ vnímání, který je podobný uchopování základních axiomů geometrie. ${ }^{66} \mathrm{Je}$ to tedy jakýsi intuitivní vjem, kterým disponuje fronésis, ale jelikož ta v sobě spojuje více úkonů, pak se na tento intuitivní vjem nedá redukovat. Spíše se jedná o jeden z jejích úkonů, který je $\mathrm{v}$ kompetenci zř̀ení (nús). Jak přesně ovšem zapadá do struktury fronésis?

Předně je třeba vyjasnit, co přesně je to onen intuitivní vjem, který zření (nús) obstarává. Výše jsem zmínil, že v praktické oblasti uchopuje vedlejší premisu praktického sylogismu. Hlavní premisa je vždy nějaký obecný požadavek, který se v případě fronésis týká uskutečňování etických zdatností (ethiké areté), případně i požadavku celkovosti. Vedlejší premisa je určitý konkrétní projev jednání v dané situaci. Závěr by poté měl vyplývat z oboru premis. Konkrétně by určitý zjednodušený příklad praktického sylogismu mohl vypadat takto: ${ }^{67}$

(i) hlavní premisa - být laskavý je zdatností (areté)

(ii) vedlejší premisa-povzbudit kolegu Tomáše tady a ted' je laskavé

(iii) závěr - povzbudit kolegu Tomáše tady a ted' je zdatností (areté)

EN 1142a28-29; srv. Synek 2011, s. 129.

Pro ilustraci praktického sylogismu jsem užil mnou upravený příklad Hughese. Hughes 2001, s. 96-97; zjednodušený přiklad je to proto, že vedlejši premisa může mít mnohem konkrétnější podobu s ohledem k dané situaci, může a velmi pravděpodobně by i měla být detailnější, ale pro ilustraci je tento zjednodušený příklad dostačujicí; o praktickém sylogismu jako takovém Aristotelés mluví, když projednává problém inkontinence (akrasia). EN 1147a25 nn.
Zření (nús) dokáže uchopit (ii) správnou vedlejší premisu se všemi jejími detailními konkrétnostmi jako uskutečnění univerzálního požadavku jednání v dané situaci. Proto Aristotelés říká, že zření (nús) dokáže z jednotlivého uchopit univerzální (katholú). ${ }^{68}$ Správné vyhodnocení a posouzení určité praktické situace obstarává správný úsudek (orthos logos), který dokáže nalézt její kontextuální střed, což je de facto zdatné jednání. V tomto směru se dá říci, že celý praktický sylogismus je v jeho kompetenci. ${ }^{69}$ Výkon zření (nús) v praktických záležitostech se tedy do určité míry překrývá s výkonem správného úsudku (orthos logos) ${ }^{70}$ Nicméně se nejedná o výkon zvažování (búleusis), chápání (synesis) ani uznání (gnómé), které jsou podřazeny správnému úsudku (orthos logos) a které jsou k výkonu zření (nús) odlišné. Zření (nús) se tak jeví jako zvláštní typ rozumové zdatnosti (dianoétiké areté), který se může zapojovat v teoretickém i praktickém myšlení. ${ }^{71}$ V oblasti praktického myšlení je to pak

EN 1143b4-5; srv. Engberg-Pedersen 1983, s. 207; Hughes 2001, s. 102.

69 Glombíček 2013, s. 384.

70 Podle Tessitoreho Aristotelovo ztotožnění fronésis s orthos logos predpokládá intuitivní vjem morálně dobrého člověka. Tessitore 1996, s. 47.

71 Shiner podřazuje fronésis i nús ve specifickém kontextu EN pod usuzovací část rozumu (to logistikon). Shiner 1979, s. 378; Pakaluk se v tomto ohledu zamýšlí nad tím, proč Aristotelés vlastně stanovil zření (nús) jako samostatnou rozumovou zdatnost, a nikoli spíše jako deduktivní schopnost. Podle něj Aristotelés vidí nús jako aktivní schopnost/zdatnost, díky níž se člověk učí ze zkušeností a dokáže z ní vytáhnout pravdu. Pakaluk 2005, s. 223. 
intuitivní schopnost v rámci praktického sylogismu - jako taková je jedním $\mathrm{z}$ podřazených úkonů správného úsudku (orthos logos), tedy usuzovací části fronésis. Konečné a úplné schéma struktury fronésis tedy vypadá následovně:

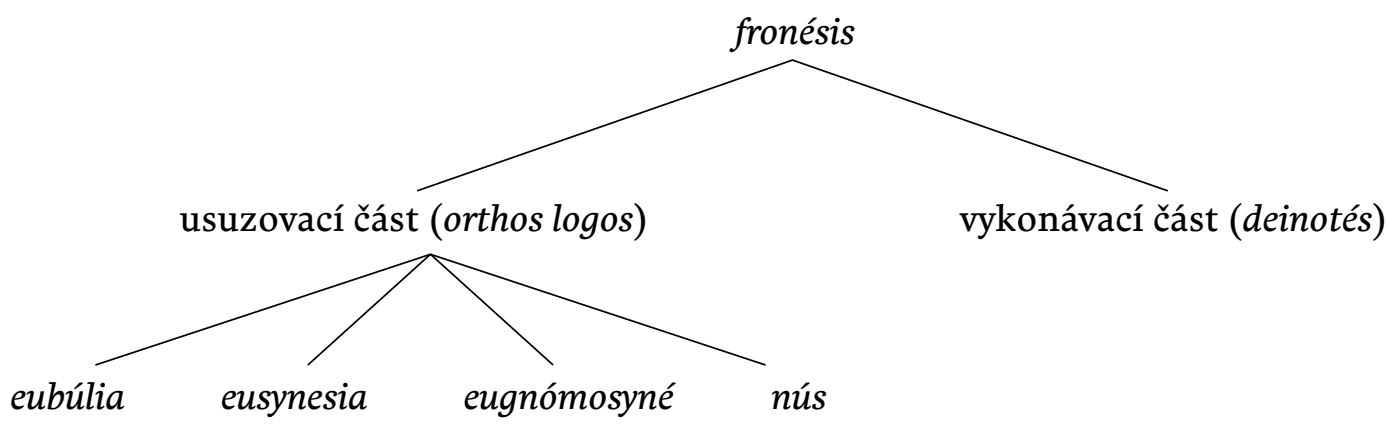

\section{Z ZÁVĚR}

V tomto článku jsem se pokusil prozkoumat povahu fronésis, určit její výměr a funkční strukturu. Fronésis je schopnost člověka správně jednat, a tato schopnost není jednolitá, ale skládá se $\mathrm{z}$ více částí, které se u rozumného člověka (fronimos) vzájemně doplňují a spolupracují. Základní části fronésis jsou dvě usuzovací a vykonávací. Usuzovací část se týká veškerého souzení (logos), které je třeba v každé konkrétní praktické situaci vykonat - jedná se tedy o veškeré kognitivní akty spojené s uvažováním. Usuzovací část fronésis je v kompetenci správného úsudku (orthos logos) a jsou jí podřízeny čtyři následující složky: rozvážnost (eubúlia) jako správnost ve výkonu zvažování, dobré chápání (eusynesia), dobré uznání (eugnómosyné) a praktické zření (nús). Všechny čtyři se totiž týkají konkrétního typu souzení (logos) a správnost v jejich výkonech tvoří dohromady správnost v usuzování ohledně konkrétní praktické situace.
Vykonávací část má poté na starosti to, že se takto správně posouzený a vyhodnocený obsah konkrétní praktické situace manifestuje $\mathrm{v}$ konkrétní podobě vykonaného činu. Zjednodušeně řečeno vykoná to, co usuzovací část uznala za nejlepší možnou podobu jednání v konkrétním kontextu. Tato schopnost vykonávací části je v kompetenci dovednosti (deinotés).

Pokud některá, byt jen jediná, z těchto částí chybí nebo není zapojena do příslušného procesu, pak se nemůže jednat o fronésis. Pouze jejich plné zapojení a kooperace umožňují praktický výkon rozumného člověka (fronimos). Mnou předložená interpretace tak představuje nejen plausibilní uchopení fronésis v Aristotelově Etice Níkomachově, ale také přináší její strukturální pojetí a vztažnost jednotlivých procesů, které jsou její nutnou podmínkou. 


\section{ZKRATKY}

Seznam zkratek citovaných děl

$L S J$

Liddell, H. G., Scott, R.

(1996). A Greek-English Lexicon, With a Revised Supplement: Jones, H. S., McKenzie, R. Oxford: Clarendon Press.

Seznam zkratek antických autorů

Aristotelés

De an.

De anima

De motu

De motu animalium

EN Ethica Nicomachea

$M M$

Magna moralia

Isokratés

Isoc. 1

Ad Demonicum

Isoc. 2

Ad Nicoclem

Isoc. 15

Antidosis 


\section{BIBLIOGRAFIE}

Aubenque, P. (2003). Rozumnost podle Aristotela. Praha: OIKOYMENH.

Burnyeat, M. F. (1980). „Aristotle on Learning to Be Good“. In: A. O. Rorty, Essays on Aristotle's Ethics, Los Angeles: University of California Press, s. 69-92.

Celano, A. J. (2016). Aristotle's Ethics and Medieval Philosophy. Cambridge: Cambridge University Press.

Curzer, H. J. (2012). Aristotle and the Virtues. Oxford: Oxford University Press.

Engberg-Pedersen, T. (1983). Aristotle's Theory of Moral Insight. Oxford: Clarendon Press.

Fortenbaugh, W. W. (2006). Aristotle's Practical Side. Leiden: Brill.

Glombíček, P. (2013). „Aristotelův pojem zdravého rozumu“. Filosofický časopis 61, s. 371-386.

Hardie, W. F. R. (1968). Aristotle's Ethical Theory. Oxford: Clarendon Press.
Hughes, G. J. (2001). Aristotle on Ethics. London: Routledge.

Hughes, G. J. (2013). The Routledge Guidebook to Aristotle's Nicomachean Ethics. London: Routledge.

Joachim, H. H. (1955). Aristotle the Nicomachean Ethics. Oxford: Clarendon Press.

Konrádová, V. (2017). „Fronésis a problém zvažování“. Filosofický časopis 65, s. 708-719.

Kontos, P. (2016). „Morální jednání u Aristotela“. In: O. Švec, Filosofie jednání, Praha: OIKOYMENH, s. 49-61.

Kosman, A. (2014). Virtues of Thought. London: Harvard University Press.

Lear, J. (2016). Aristotelés: Touha rozumět. Praha: OIKOYMENH.

MacIntyre, A. (1988). Whose Justice? Which Rationality? Notre Dame: University of Notre Dame Press.

Nussbaumová, M. (2003). Křehkost dobra. Praha: OIKOYMENH. 
Pakaluk, M. (2005). Aristotle's Nicomachean Ethics. Cambridge: Cambridge University Press.

Reeve, C. D. C. (2006). „Aristotle on the Virtues of Thought". In: R. Kraut, Aristotle's Nicomachean Ethics, Oxford: Blackwell Publishing, s. 198-217.

Rorty, A. O. (1988). „Virtues and Their Vicissitudes". Midwest Studies in Philosophy 13, s. $136-148$.

Russell, D. C. (2014). „Phronesis and Virtues (NE vi 12-13)“. In: R. Polansky, The Cambridge Companion to Aristotle's Nicomachean Ethics, Cambridge: Cambridge University Press, s. 203-220.

Shiner, R. A. (1979). „Aisthesis, Nous and Phronesis in the Practical Syllogism“. Philosophical Studies 36, s. 377-388.

Schollmeier, P. (1989). „Aristotle on Practical Wisdom". Zeitschrift für philosophische Forschung 43, s. 124-132.

Sorabji, R. (1996). „Aristotelés o důležitosti rozumu pro zdatnost“. In: P. Rezek, Spra- vedlnost jako zdatnost, Praha: OIKOYMENH, s. 24-44.

Synek, S. (2011). Lidská přirozenost jako úkol člověka. Praha: Togga.

Špinka, Š. (2014). „Blaženost smrtelných bytostí: Aristotelés“. In: Š. Špinka, Př́stupy k etice I., Praha: Filosofia, s. 11-45.

Tessitore, A. (1996). Reading Aristotle's Ethics. New York: State University of New York Press.

Tuozzo, T. M. (1991). „Aristotelian Deliberation Not of Ends“. In: J. P. Anton, A. Preus, Essays in Ancient Greek Philosophy IV, Albany: Suny Press, s. 193-212.

Urmson, J. O. (1995). Aristotle's Ethics. Oxford: Blackwell Publishers.

Verbeke, G. (1994). „L'éducation morale et les arts chez Aristote et Thomas D’Aquin.“ In: I. Craemer-Ruegenberg, A. Speer, Miscellanea Mediavalia 22, Scientia und ars in Hoch-und Spätmittelalter, Berlin: de Gruyter, s. 449-467. 
White, N. (1995). „Conflicting Parts of Happiness in Aristotle's Ethics“. Ethics 105, s. 258-283.

Wiggins, D. (1980). „Deliberation and Practical Reason". In: A. O. Rorty, Essays on Aristotle's Ethics, Los Angeles: University of California Press, s. 221-240. 